\title{
Aging Prisoners: A Brief Report of Key Legal and Policy Dilemmas
}

\author{
Israel Issi Doron ${ }^{1, *}$ and Helene Love ${ }^{2}$ \\ ${ }^{1}$ Department of Gerontology, University of Haifa, Haifa, Israel \\ ${ }^{2}$ Faculty of Law, University of British Columbia, Canada
}

\begin{abstract}
Background: The social phenomenon of the aging of the prison population has raised various legal and policy challenges.

Objective: The goal of this brief report is to describe the current key legal-policy dilemmas in this field.

Methods: A computerized search for legal documents, articles and studies using relevant key words was conducted in computerized databases.

Results: Five key dilemmas were found: (1) Early and compassionate release of older prisoners; (2) Segregation or integration of older prisoners; (3) Heaven or hell? The meaning of imprisonment in old age; (4) Fixed v. tailored sentences to older offenders; and (5) Is prison the right place to send older offenders?

Conclusion: Evidence regarding the unique socio-medical needs of older prisoners does not provide easy or simple answers to the legal-policy dilemmas in this field. Hence, as of today, the scholarly discussions in this field seem to be more normative (what "should" be the solution) rather than empirical (what "is" the evidence-based solution). Therefore, more empirical evidence is needed in order to design old-age based legal-policies towards older prisoners.
\end{abstract}

Keywords: Older prisoners, elderly prisoners, elder law, geriatric jurisprudence, jurisprudential gerontology.

\section{INTRODUCTION}

In various countries around the world, there is increasing concern about the growing number of older prisoners (Adams Jr, 1994; Atabay, 2009; Ornduff, 1996; Walmsley, 2007). In some countries, older prisoners represent the fastest growing age group in prison. In the United States, for example, had over fourteen times as many prisoners over age 55 in 2011 as it did in 1981, and experts project that by 2030 , prisoners aged 55 and older will comprise over onethird of those in prison (Aday, 2003; Chettiar, Bunting, \& Schotterat, 2012; HRW, 2012). Japan, as another example, experienced an increase in its older prisoners' population of $216 \%$ between 2000 and 2006 (Atabay, 2009).

The social phenomenon of the aging of the prison population has raised various social policy issues, challenges and dilemmas. For example, aging prisoners are not only the fastest growing segment of the penal population, but they are also the most care demanding and expensive group to house in prison (Binswanger, Krueger, \& Steiner, 2009; Loeb \& AbuDagga, 2006; Rikard \& Rosenberg, 2007). The health issues that accompany old age have given rise to new challenges in the provision of health care services to older prisoners with growing need for longterm care due to chronic diseases, physical

*Address correspondence to this author at the Department of Gerontology, University of Haifa, Haifa, Israel; Tel: 972-(0)4-8249954;

Fax: 972-(0)4-8249946; E-mail: idoron@univ.haifa.ac.il disabilities, cognitive impairments such as dementia, or the need for mental and hospice care (Fazel, Hope, O'Donnell, Piper, \& Jacoby, 2001; Kakoullis, Le Mesurier, \& Kingston, 2010; Tina Maschi, Kwak, Ko, \& Morrissey, 2012; Stone, Papadopoulos, \& Kelly, 2012; Wilson \& Barboza, 2010). In this brief report, we will not attempt to analyze or address the full scope of these complex socio-medical issues. The purpose of this report is much narrower, and will attempt to summarize and focus only on current key legal-policy dilemmas in this field.

\section{METHODS}

The search and review of the scholarly references to the legal issues around older prisoners consisted of two computerized searches that took place during the month of October, 2012, using the keywords: "older prisoners"; "aging prisoners"; "older inmates"; "old age and sentencing"; and "prisons and old age". The first was based on a search in the well-known computerized databases: WestLaw, HeinOnline and PubMed. In WestLaw, we conducted a Boolean full text search for these phrases in the "Law Reports and Journals" category with an unrestricted time frame. This search resulted in six law journal articles. In HeinOnline, we searched all subscribed collections for these terms subject to the delimiters of law journals (collection library) and articles (collection type). This resulted in 322 articles. In PubMed we conducted an open search (in all optional search fields) of the key words listed above, which resulted in 135 articles. 
Of the articles retrieved under these searches, we screened those that did not explicitly deal with a legal or a policy issue in their abstracts. We defined a legal and policy issue to be a question that engages the applicable law and/or the broader policy instruments, and were looking for articles that dealt squarely with the incarceration of older adults. The formal criteria for inclusion were the direct discussion on all the following issues: older prisoners; socio-legal policies; structured normative and/or empirical analysis. The analysis of the retrieved articles was not quantitative but qualitative, i.e. identifying the key legal-policy themes that were raised or addressed, either empirically or normatively. The key themes were extracted according to the hermeneutical method (Creswell, 2006). All articles were carefully read allowing for an in-depth acquaintance with the text. Key topics were coded and grouped into unique categories. Different sub-topics that had similar content were connected and unified to create an organized list of key themes, which will be described below.

\section{RESULTS: KEY LEGAL AND POLICY DILEMMAS REGARDING OLDER PRISONERS}

Throughout the years, various international and regional documents have addressed the universal human rights of prisoners in general. For example, Article 1 of the UN 1990 Basic Principles for the Treatment of Prisoners declares that "All prisoners shall be treated with the respect due to their inherent dignity and value as human beings." In similar lines, Article 3 of the European Convention on Human Rights prohibits the "inhumane or degrading treatment or punishment."

However, the specific legal and human right issues of older prisoners have received relatively little attention. This is reflected in key human rights and policy documents in the field of aging (e.g. MIPAA Madrid International Plan of Action on Aging or the UN Proclamation on Aging), that fail to mention or address the rights of older prisoners as a unique or specific group within the older population (Chettiar, et al., 2012; Howse, 2006; HRW, 2012). This is also part of the general UN neglect to establish a specific human rights convention for older persons (I Doron \& Apter, 2010). The only (non-binding) UN document that directly addresses this group is the UNODC (United Nations Office on Drugs and Crime) report on Prisoners with Special Needs (Atabay, 2009).

Summarizing the existing literature above and recent reports in the field reveal the following key legal and policy issues:

\section{Early and Compassionate Release}

One central legal dilemma that appears in the literature is around the question of whether older inmates should be released from prison due to their old age, for compassionate reasons, or as practical solution to prison overcrowding. For example, in the United States this issue was raised as an outcome of stricter sentencing laws, mandatory prison terms and overly punitive policies (Rikard \& Rosenberg, 2007; Williams, Sudore, Greifinger, \& Morrison, 2011). Such arguments are based on assumptions that older prisoners may be less dangerous, are in better position to reform themselves, are more likely to suffer from chronic illness or disability, or are less likely to return to criminality (Chettiar, Bunting, \& Schotterat, 2012, Curtain, 2007; Fazel, 2002).

For example, in the United States, a program founded in the 1980s by Prof. Jonathan Turley known as POPS - the Project for Older Prisoners, advocates for the early release of prisoners fifty-five and older who have been evaluated as unlikely to commit further crimes in the future, and the victim or the victim's family agrees to the early release. The program follows the released older prisoners and assists them with finding a job, housing, and receiving social security rights (Ornduff, 1996).

In recent years, other countries (e.g. France) have introduced a system of medical parole which permits the early release of any prisoner suffering from a terminal condition, or more generally, whose state of health is incompatible with continued detention. This relatively new legislation has been applied in the high profile case of Papon, where a 92 year old convicted war criminal was released on grounds of poor health, after serving less than three of a ten-year sentence for crimes against humanity (Steiner, 2003).

On the other hand, one may raise the question: is old age truly relevant in the context of early release? Studies in the field of penology provide details of court decisions that suggest that old age, as such, should not be a relevant factor in the sentencing of older adults. In those cases, the argument is that an older prisoner should be punished for his or her wrong doing whether they are $35,55,60,75$ years of age. Age, in and by itself, does not negate the punitive rationales of punishment, deterrence, or the protection of the public by incarceration (Love, 2011). 


\section{Segregation or Integration}

Another key legal dilemma with regard to the appropriate legal policy toward older prisoners is whether they should be integrated or segregated from the general prison population (Kerbs \& Jolley, 2009). If viewed as weak and unable to protect themselves from younger and more dangerous criminals, then segregating older prisoners makes sense (Aday \& Krabill, 2006; (Stojkovic, 2007). One can also find support in the literature for the argument that older prisoners find it easier to associate and socialize with prisoners at their age, and find the segregated environment safer and more accommodating (Curtain, 2007; Kerbs \& Jolley, 2007). Another relevant consideration is that rehabilitation can be more effective in a segregated environment, while education and recreation programs can be tailored to the unique needs of the older prisoners (Gillespie \& Galliher, 1972). Finally, there is also a cost-effective argument for saving money through centralized healthcare for older prisoners (Curtain, 2007; Fazel, 2002).

On the other hand, there are those who argue that integration of older prisoners is a win-win situation. Older prisoners can serve as mediators and leaders to reduce prison tensions within the younger prison population (Aday \& Krabill, 2006; Mabli, Holley, Patrick $\&$ Walls, 1979). Moreover, the segregation of the older prison population may allow for them to be discriminated against and excluded from various programs such as mental-health services, rehabilitation, employment, and education (ThiviergeRikard \& Thompson, 2007). Hence, from an anti-ageist approach, integration of older prisoners can serve as a social instrument to break down negative stereotypes and biases towards old age and actually provide them better care. For example, the Council of Europe's Recommendation No. R (98) 7 in Section 50, stresses the need for integration of older prisoners and mainstreaming old age, as follows:

50. Prisoners with serious physical handicap, and those of advanced age, should be accommodated in such a way as to allow as normal a life as possible and should not be segregated from the general prison population. Structural alterations should be effected to assist the wheelchair-bound and handicapped on lines similar to those in the outside environment.

\section{Heaven or Hell? The Social Construction Dilemma Around the Meaning of Imprisonment in Old Age and its Legal Implications}

The legal dilemmas around older prisoners reflect to a large extent our social understanding and construction of the unique meaning of the incarceration of older persons. This interpretive dilemma is reflected in the two opposite meanings that can be found in the existing literature. One describes the experience of older prisoners in dark colors: older prisoners experience fear, violence, humiliation, and lack of appropriate health care or specialized social care (Ginn, 2012). As a result, not only do they deteriorate physically and mentally, but they experience stress, trauma, and may become more dependent on the warders and the prison authorities (Gillespie \& Galliher, 1972; Kerbs \& Jolley, 2007; Tina Maschi et al., 2011).

The opposite view depicts incarceration as a safe haven: a place where older criminals can receive a proper meal, and safe place to sleep, and an environment that provides free quality health care services that were not available to that population outside prison walls. For example, Reed and Glamser (Reed \& Glamser, 1979), found that most of the older prisoners they interviewed considered prison life to be a positive experience, stating that, among other things, they felt younger and enjoyed more pleasant living conditions in prison. Along similar lines, Gallagher (Gallagher, 1990) found that when compared with younger inmates, the older men had more contacts with friends and family, more friends in prison, and experienced less stress than the younger men.

Reality, as usual, is more complex and more recent studies have stressed this ambiguity. For example, a qualitative study in this field (Doron, 2007) has shown that the prisoners' experiences include mixed elements of both the benefits of being consider "older" (e.g. receiving greater respect from both staff and younger prisoners) along with negative impacts of their old age (e.g. fear from younger prisoners, or heavier family stress as being parents or grandparents). Therefore, it is inappropriate to resolve this constructionist dilemma by painting imprisonment in old age in simple "black and white" colors but rather work to improve exiting empirical evidence and knowledge in the field (Lemieux, Dyeson, \& Castiglione, 2002).

\section{Fixed v. Tailored Sentences}

The fact that older adults are the fastest growing segment of the prison population is due in part to the 
graying of the general population at large, but is also an outcome of sentencing policies which emphasize determinate sentences (Rothman, Dunlop, \& Entzel, 2004). The debate is between doling out harsh sentences to criminals for serious crimes versus tailoring a sentence that is appropriate considering the age, health, and other personal characteristics of accused is rife in criminal sentencing.

On one side of the debate are mandatory sentencing policies, with the United States presenting an extreme example. Mandatory sentencing policies include obligatory minimum sentences (where an offender is required to serve a minimum amount of time in prison based on the type of offence committed); habitual offender laws (where a prison term is fixed based on the offender's history of recidivism); and "truth in sentencing" laws (where an offender is required to serve out a minimum proportion of his or her sentence, usually 85\%) (Chettiar, et al., 2012). Beyond the injustice of imposing a "standard" sentence regardless of the unique personal circumstances, the upswing in these types of non-discretional sentencing policies are said to be responsible for the explosion of aging prisoners in the United States because more individuals are sent to prison, and those in prison stay there longer (Auherhan, 2012).

On the other hand are discretionary sentencing regimes, like Canada's, where (with a few exceptions) criminal sentences are crafted to fit the individual circumstances of the offender and the offence. Under discretionary sentencing policies, the aging prison population has still increased, but at a significantly lower rate (Sapers, 2012). Moreover, within discretionary sentencing regimes, various personal variables that are relevant to old age (e.g. medical condition, familial relationships) can be taken into account (Cavan, 1987; Love, 2012; Sapers, 2012).

\section{Is Prison the Right Place to Send Older Offenders?}

Finally, tied to the policy debates surrounding fixed sentences and the type of institution where it is appropriate to send an older offender is the issue of whether prison is even the right place to send an older offender. Where an older offender has health issues that prevent him or her from re-offending or where the underlying offence is minor and unrelated to public danger, then there is little or no danger to the community in exploring alternatives to prison sentences (Fazel, 2002).
Guiding the use of non-prison sentences are the principles of proportionality, deterrence, denunciation, and the protection of the public. For minor offences, community notices, fines, restitution orders, denial of public benefits, and community services are types of non-prison punishments that are available for sentencing judges. For more serious crimes, confinement in non-prison settings can be substituted for prison terms. For example, an offender could serve his or her sentence in the community (subject to specified restrictions), a treatment facility, a hospital, in house arrest, or a halfway house. Restrictions can also include community service or occupational restrictions designed to protect the public (Demleitner, 2005).

Allowing greater flexibility in the type of institution where an older adult serves their sentence addresses concerns about prison overcrowding, the costs of providing medical care, and the social concerns surrounding older prisoners. However, there remains the public perception that sentences served in the community may not be punishment enough for the crimes of these offenders, and denunciation may be negatively impacted.

\section{CONCLUDING THOUGHTS: IS THERE A NEED FOR "AGE SPECIFIC" LEGAL POLICY FOR OLDER INMATES?}

While the issues discussed in this paper may seem universal and relevant to various special prison populations, the impact of the legal and policy matters reviewed here is particularly acute in the case of older inmates. Not only are they the fastest growing segment of the prison population, but they are also the most care demanding and expensive group of prison population. It not surprising then, that in a very recent article, the authors argued that (T. Maschi, Viola, \& Sun, 2012): "older adults in prison have unique individual and social developmental needs that result from life course exposure to cumulative risk factors compounded by prison conditions that accelerate their aging." (p. 543).

Indeed, as provided above, there is growing evidence for the unique and growing socio-medical needs of the aging prison population. However, as the different arguments presented in this review reveal, this evidence alone does not resolve any of the key legalpolicy dilemmas (Cavan, 1987). For example, evidence in the field cost-effectiveness of alternatives to imprisonment is not based on age-specific policies (Schmitt, Warner, \& Gupta, 2010). The limited evidence regarding the dilemma around segregation $v$. integration of older prisoners is contradictory (Kerbs \& 
Jolley, 2007, 2009; Mabli, et al., 1979). Findings of trauma or stress in older inmates do not necessarily imply solutions that are age-based rather than needsbased. Finally, in the criminological and gerontological literature, questions are raised regarding the relevance of "old age" as opposed to concepts of "cohorts" "generations" or "time periods" (Rikard \& Rosenberg, 2007).

In other words, recognizing that older prisoners are more likely to experience medical or social problems in the prison environment does not automatically mean that differential-legal treatment will actually be a better solution for them or for the society at-large. Without empirical evidence to support such age-specific legal policies (as opposed to more universal or individualability based policies), at least at this stage of the development of knowledge in this field, the discussion in the legal field seems to be more normative (what "ought" to be the solution) rather than empirical (what the empirical evidence suggests is the better legalpolicy solution).

In his analysis of the relationships between law and aging, Doron has proposed a multi-dimensional model to describe this field of law (Doron, 2003). The first legal dimension includes universal and fundamental legal values, based on human rights. This dimension provides the older population with a universal protection of the based on an anti-ageist policy. Older rights are protected not by their legal exclusion or separation, but rather by their legal inclusion and streamlining. Their legal status is maintained by a liberal argument that they should be treated equally and fairly - but not differently.

We would argue that such universalistic and antiageist approach should be taken into account while designing a legal policy toward older inmates in light of the growth in the older prison population. Without sufficient and specific empirical basis, it seems that old age, as such, should not be the sole basis for different legal treatment to older prisoners (Cavan, 1987). From a human-rights approach, prisoners at all ages should receive humane, dignified and professional incarceration. Relevant and material personal variables, such as physical condition, disability, mental status, or risk to self or others, should all be taken into account on an individual basis not based on stereotypes or social construction of age. Rehabilitation, education and recreation programs in the prisons should be shaped to fit these personal characteristics.

This does not mean that prisoners with special needs, such as medical, physical or social needs should be ignored (e.g. prisoners with dementia or with mental-health issues). It also does not mean that professional staff in prisons should not be knowledgeable on aging, or be aware of the unique experiences of older prisoners. It means that policy makers need to be aware of the fact that a legal policy based solely on chronological age can potentially symbolize and emphasize ageism and deepen inappropriate and unsupported negative and positive social construction of old age (Eglit, 2004; Palmore, 1999). Hence, more specific and focused research is needed to examine the question of whether the prison population in general, and the older prisoners in specific, would benefit from a universal jurisprudential policy based on human rights, equality and fairness rather than legal policies based on chronological age groupings.

\section{REFERENCES}

Adams Jr, William. E. 1994. "Incarceration of Older Criminals: Balancing Safety, Cost, and Humanitarian Concerns." Nova Law Review, 19: 465-486.

Aday, Ronald H. 2003. Aging prisoners: Crisis in American corrections. Westport, CT: Greenwood Publishing Group.

Atabay, T. 2009. Handbook on Prisoners with Special Needs. Vienna, Austria: UN.

Auerhahn, Kate. 2012. Criminal Sentencing Policy and Aging Prison Populations. In Tina Maschi, Mary B. Morrissey, R. Immarigeon \& S. Sutfin (Eds.), Ageing Prisoners: A Crisis in Need of Intervention. . USA: Fordham University Be the Evidence Project.

Binswanger, Ingrid A., Krueger, P. M., \& Steiner, J. F. 2009 "Prevalence of chronic medical conditions among jail and prison inmates in the USA compared with the general population." Journal of epidemiology and community health, 63(11): 912-919.

http://dx.doi.org/10.1136/jech.2009.090662

Cavan, Ruth S. 1987. "Is Special Treatment Needed for Elderly Offenders?" Criminal Justice Policy Review, 2(3): 213-224. http://dx.doi.org/10.1177/088740348700200301

Chettiar, Inimai., Bunting, Will., \& Schotterat, Geoff. 2012. At America's Expense: The Mass Incarceration of the Elderly. New York, NY: American Civil Liberties Association.

Creswell, John. W. 2006. Qualitative Inquiry And Research Design: Choosing Among Five Approaches. NY: Sage Publications, Inc.

Demleitner, Nora. 2005. "Smart Public Policy: Replacing imprisonment with non-prison sentences and collateral sanctions". Stanford Law Review, 58(1): 339-360.

Doron, Israel. 2003. "A multi-dimensional model of elder law: An Israeli example." Ageing International, 28(3): 242-259. http://dx.doi.org/10.1007/s12126-002-1006-0

Doron, Israel. 2007. "Heaven or Hell? Aging Behind Bars in Israel." Hallym International Journal of Aging, 9(2): 145-159. http://dx.doi.org/10.2190/HA.9.2.e

Doron, Israel., \& Apter, lapter. 2010. "The Debate Around the Need for an International Convention on the Rights of Older Persons." Gerontologist. doi: gnq016 [pii]10.1093/geront/ gnq016

Eglit, Howard C. 2004. Elders on trial: age and ageism in the American legal system. Gainesville, FL.: University Press of Florida. 
Fazel, Seena., Hope, Tony., O'Donnell, lan., Piper, Mary., \& Jacoby, Robin. 2001. "Health of elderly male prisoners: worse than the general population, worse than younger prisoners." Age and ageing, 30(5): 403-407.

http://dx.doi.org/10.1093/ageing/30.5.403

Gallagher, Elaine. M. 1990. "Emotional, social, and physical health characteristics of older men in prison." The International Journal of Aging and Human Development, 31(4): 251-265. http://dx.doi.org/10.2190/QE9H-GV5T-KCJ6-EMJ4

Gillespie, Michael., \& Galliher, John. 1972. Age, anomie, and the inmates' definition of aging in prison: An exploratory study. NY: Research Planning and Action for the Elderly, Behavioural Publications.

Ginn, Stephen. 2012. "Elderly prisoners." BMJ: British Medical Journal, 2012: 345.

Howse, Ken. 2006. Growing Old in Prison: A Scoping Study on Older Prisoners. London: Centre for Policy on Ageing and Prison Reform Trust.

HRW, Human Rights Watch. 2012. Old Behind Bars: The Aging Prison Population in the United States. Washington DC.

Kakoullis, Alexander, Le Mesurier, Nick, \& Kingston, Paul. 2010. "The mental health of older prisoners." International Psychogeriatrics, 22(5): 693-701. http://dx.doi.org/10.1017/S1041610210000359

Kerbs, John. J., \& Jolley, Jennifer. M. 2007. "Inmate-on-inmate victimization among older male prisoners." Crime \& Delinquency, 53(2): 187-218. http://dx.doi.org/10.1177/0011128706294119

Kerbs, John J., \& Jolley, Jennifer M. 2009. "A Commentary on Age Segregation for Older Prisoners Philosophical and Pragmatic Considerations for Correctional Systems." Criminal Justice Review, 34(1): 119-139. http://dx.doi.org/10.1177/0734016808324245

Lemieux, Catherine M., Dyeson, Timothy B., \& Castiglione, Brandise. 2002. "Revisiting the Literature on Prisoners who are Older: Are we Wiser?" The Prison Journal, 82(4): 440-458. http://dx.doi.org/10.1177/0032885502238680

Loeb, Susan J., \& AbuDagga, Azza. 2006. "Health related research on older inmates: An integrative review." Research in nursing \& health, 29(6): 556-565. http://dx.doi.org/10.1002/nur.20177

Love, Helene. 2011. "Sentencing Practices for Older Adults." Canadian Bar Review, 89(3): 729-759.

Mabli, Jerome, Holley, Charles, Patrick, Judy, \& Walls, Justina. 1979. "Age and Prison Violence Increasing Age Heterogeneity as a Violence-Reducing Strategy in Prisons." Criminal justice and behavior, 6(2): 175-186. http://dx.doi.org/10.1177/009385487900600206

Maschi, Tina, Dennis, Kelly S., Gibson, Sandy, MacMillan, Thalia, Sternberg, Susan, \& Hom, Maryann 2011. "Trauma and stress among older adults in the criminal justice system: A review of the literature with implications for social work." Journal of Gerontological Social Work, 54(4): 390-424. http://dx.doi.org/10.1080/01634372.2011.552099

Maschi, Tina, Kwak, Jung, Ko, Eunjeong, \& Morrissey, Mary B. 2012. "Forget me not: Dementia in prison." The Gerontologist, 52(4): 441-451. http://dx.doi.org/10.1093/geront/gnr131
Maschi, Tina, Viola, Debora, \& Sun, Fei. 2012. "The High Cost of the International Aging Prisoner Crisis: Well-Being as the Common Denominator for Action." Gerontologist, 53(4): 543554.

http://dx.doi.org/10.1093/geront/gns125

Ornduff, Jason S. 1996. "Releasing the elderly inmate: A solution to prison overcrowding." Elder Law Journal, 4: 173-205.

Palmore, Erdman. 1999. Ageism: Negative and positive. NY: Springer Publishing Company.

Reed, Monika B., \& Glamser, Francis D. 1979. "Aging in a total institution: The case of older prisoners." The Gerontologist, 19(4): 354-360. http://dx.doi.org/10.1093/geront/19.4.354

Rikard, R., \& Rosenberg, Ed. 2007. "Aging inmates: A convergence of trends in the American criminal justice system." Journal of Correctional Health Care, 13(3): 150-162. http://dx.doi.org/10.1177/1078345807303001

Rothman, Max B., Dunlop, Burton D., \& Entzel, Pamela. 2004. Elders, crime, and the criminal justice system: Myth, perceptions, and reality in the 21st century. NY: Springer Pub Co.

Sapers, H. 2012. Annual Report of The Office of the Correctional Investigator 2010-2011. Retrieved September 30, 2012, 2012, from http://www.oci-bec.gc.ca/rpt/annrpt/annrpt 20102011-eng.aspx

Schmitt, John, Warner, Kris, \& Gupta, Sarika. 2010. The high budgetary cost of incarceration. Washington, DC: Center for Economic and Policy Research. http://www.cepr.net/ documents/publications/incarceration-2010-06. pdf.

Steiner, Eva. 2003. "Early release for seriously ill and elderly prisoners: Should French practice be followed?" Probation Journal: The Journal of Community and Criminal Justice, 50(3): 267-276.

Stojkovic, Stan. 2007. "Elderly prisoners: A growing and forgotten group within correctional systems vulnerable to elder abuse." Journal of Elder Abuse \& Neglect, 19(3-4): 97-117. http://dx.doi.org/10.1300/J084v19n03 06

Stone, Katie, Papadopoulos, Irena, \& Kelly, Daniel. 2012. "Establishing hospice care for prison populations: An integrative review assessing the UK and USA perspective." Palliative Medicine, 26(8): 969-978. http://dx.doi.org/10.1177/0269216311424219

Thivierge-Rikard, R., \& Thompson, Maxine. S. 2007. "The association between aging inmate housing management models and non-geriatric health services in state correctional institutions." Journal of Aging \& Social Policy, 19(4): 39-56. http://dx.doi.org/10.1300/J031v19n04 03

Walmsley, Roy. 2007. World prison population list. King's College London, International Centre for Prison Studies.

Williams, Brie A., Sudore, Rebecca L., Greifinger, Robert, \& Morrison, Sean. 2011. "Balancing punishment and compassion for seriously ill prisoners." Annals of internal medicine, 155(2): 122-126. http://dx.doi.org/10.7326/0003-4819-155-2-201107190$\underline{00348}$

Wilson, John., \& Barboza, Sharen. 2010. "The looming challenge of dementia in prisons." Correctional Care, 24(2): 10-13.

Received on 29-07-2013

Accepted on 23-08-2013

Published on 27-08-2013

\section{DOl: http://dx.doi.org/10.6000/1929-4409.2013.02.31}

(c) 2013 Doron and Love; Licensee Lifescience Global.

This is an open access article licensed under the terms of the Creative Commons Attribution Non-Commercial License (http://creativecommons.org/licenses/by-nc/3.0/) which permits unrestricted, non-commercial use, distribution and reproduction in any medium, provided the work is properly cited. 